\title{
SUSTAINABLE DEVELOPMENT GOALS AND SOCIO-ECONOMIC DEVELOPMENT THROUGH TOURISM IN CENTRAL AFRICA: MYTH OR REALITY?
}

\author{
Albert N. KIMBU \\ University of Surrey, School of Hospitality and Tourism Management, UK, \\ and University of Johannesburg, South Africa, e-mail: a.kimbu@surrey.ac.uk
}

Tembi M. TICHAAWA*

University of Johannesburg, School of Tourism and Hospitality, College of Business and Economics, Bunting Road, Johannesburg, South Africa, e-mail: tembit@uj.ac.za

\begin{abstract}
Citation: Kimbu A.N., \& Tichaawa M.T. (2018). SUSTAINABLE DEVELOPMENT GOALS AND SOCIO-ECONOMIC DEVELOPMENT THROUGH TOURISM IN CENTRAL AFRICA: MYTH OR REALITY? GeoJournal of Tourism and Geosites, 23(3), 780-796. https://doi.org/10.30892/gtg.23314-328
\end{abstract}

\begin{abstract}
The realisation by many developing countries in the last two decades that tourism can be an important tool in achieving the sustainable development goals of poverty elimination, environmental sustainability and decent work and economic growth in general has led many governments to introduce measures aimed at promoting the development of the industry. However unlike many countries in Eastern and Southern Africa, countries in the biodiversity rich Central African sub-region only recently started to adopt measures aimed at the sustainable development of the industry geared towards the realisation of these goals. The travel and tourism industry here is still at an embryonic and chaotic stage of development, plagued with a multitude of challenges contributing less than $3 \%$ to GDP and employment. Using qualitative research methods i.e. semi-structured interviews and field observations, the paper examines the role of the tourism industry in the attainment of these goals and consequently tourism's contribution to local economic development in Cameroon. It highlights the country's diverse potentials as well as some of core challenges which are presently being encountered. The paper concludes by proposing a framework within which all stakeholders can actively work together towards the realisation of these goals.
\end{abstract}

Key words: Tourism, sustainable development goals, local economic development, environmental conservation, Central African sub-region, Cameroon

\section{INTRODUCTION}

The sustainable development, conservation and use of environmental resources for tourism purposes is one of the tools that is seen by many developing countries, especially those in the sub-Saharan Africa in attaining Sustainable Development Goals

\footnotetext{
* Corresponding author
} 
(SDGs) dealing with eradication of poverty (SDG 1) and hunger (SDG 2) and ensuring environmental sustainability (SDG 15), thereby promoting Local Economic Development (LED). Evidence suggest that in contemporary pan-African context, while most economies have embraced tourism as a recommended tool to achieve such SDGs (World Bank, 2018) by successfully investing in its development (Bakker \& Messerli, 2017), others, particularly those located in the Central African sub-region have acknowledge the sector's potential but not as yet, capitalised on the opportunity it represents (Christie et al., 2014). Although some efforts have been made by a handful of governments in the sub-region particularly those in Cameroon and Gabon with regards to improving and increasing level of environmental protection, tourism's impact as a vehicle for LED has not been maximised. While briefly discussing some of the theories of LED in relation to tourism, this study appraises some of the challenges that could make the successful attainment of SDGs of ending poverty and guaranteeing environmental sustainability through tourism a distant reality in Cameroon in particular and the sub-region in general, and proposes a framework which if adopted, could help in changing this trend and thus make LED through tourism a reality. Such a framework we argue, if coupled with the country's bilingual character (English and French are the official languages), natural and cultural biodiversity, are key elements which if well exploited could lead to the development of a vibrant tourism sector which could go a long way to enabling the attainment the SDGs of poverty eradication and environmental conservation and sustainability, thereby fostering LED. However, since the adoption of the SDGs, the use of tourism to achieve some of its objectives has received a rather mixed reception in Cameroon in particular in spite promises of development and investment by the government in the sector.

This paper also examines the main challenges and contradictions presently being encountered in the use of tourism as a tool for the realisation of these goals and LED in general in Cameroon, with the main objective being to develop a strategic framework which will see the institution and integration of core and enabling mechanisms that will facilitate the attainment of these goals and thereby promoting LED.

\section{LED and the MDGs}

The advent of democracy in many developing countries in the early 1990s and the imposition of structural adjustment programmes by international financial institutions and donors on these countries during this same period aimed at poverty reduction and therefore the attainment of an important SDG led to a gradual shift from formerly centralised planning to more regional and communal planning. LED which had hitherto been centrally planned became in theory the responsibility of regional, municipal and communal governments who were now called upon to develop strategies aimed at local economic revitalisation and stimulating job creation. Wolfe and Creutzerg (2003) observed that local development strategy involves three different phases or waves, the traditional approach, the capacity building strategy and the development of information flows phase. The traditional approach was predominant from the 1950 s to the mid 1980 s. Governments and regions tried during this period to attract firms by emphasising the presence of cheap factor costs, providing subsidies and tax rebates to potential investors. Thus some risks associated with first-movers were reduced. The capacity building strategy became popular in the 1980 s when firms realised that offering the concessions in the traditional approach was not enough to lure firms to invest in regions without the necessary qualified human resources to work in the industries. As a result, focus was placed by governments and regions in creating the necessary competitive knowledge base needed to work in industry through the creation of schools and other 
educational and technological infrastructures. In so doing, knowledge transfer from schools to industry was enhanced and work and management skills needed in enterprises were honed. The development of information flows and the quality of life is an emerging strategy of LED. In this strategy, the role of the local governments is to put in place the necessary infrastructure that will not only guarantee access to information but ensure efficiency in the dissemination of this information to all those interested.

Because destinations become increasingly competitive, the quantity and quality of information available about the characteristics of the tourism products on offer in a particular locality play a very important role in making a destination attractive / popular or not. Accordingly, it is plausible to suggest that LED related activities should be geared towards encouraging active stakeholder participation in every locality or community. Nevertheless, there exists no single model of how to implement LED nor strategies and actions to adopt, due to the fact that factors that are mainly linked to efficiency and effectiveness of regional development are influenced by a range of institutions and processes. Besides, according to several studies (see for example Rogerson, 2002, 2006, 2015, 2016; Rogerson \& Rogerson, 2010; Ilies et al., 2016; Ilies et al., 2018 a, Gozner et al., 2016), certain parameters are always necessary if LED initiatives and programmes are to be successful. These include:

- The emergence and support of local role models.

- The creation or formation of institutional intermediaries

- Equitable and active stakeholder participation and ownership

- The provision of financial and technical resources

- Good governance and stringent accountability mechanisms

- Identification of sustainable income generating opportunities for the local community, particularly for the poor

- Development and implementation of monitoring indicators to measure progress

With the above discussion in mind, LED therefore involves the establishment ofenvironments that encourage the stimulation of new opportunities in both rural and urban regions with limited opportunities for economic growth. In communities near or within Cameroon's nature parks and reserves, LED could be promoted through the development of sustainable ecotourism activities which if well executed will go a long way in accomplishing the SDGs linked to poverty alleviation/eradication and environmental sustainability.

\section{STUDY CONTEXT}

Cameroon has always been described as "Africa in miniature or all of Africa in one country" (MINTOUR, 2011) because of its geographical and multicultural diversity. Located at the crossroads between west and central Africa, Cameroon has a total surface area of 475 $442 \mathrm{~km}^{2}$ and a population of about 24.68 million inhabitants in 2018. In 2005, the literacy rate was estimated at 81.1 percent, one of the highest on the African continent (NIS, 2005; $\mathrm{BBC}$, 2008). It is bound by Equatorial Guinea to the southwest, Gabon to the south, Congo to the southeast, the Central African Republic to the east, Chad to the northeast, Nigeria to the northwest and the Gulf of Guinea to the west (Figure 1) (Kimbu, 2017). Cameroon is ergo in a very fertile ground for the development of nature-based tourism activities which if well managed, could effectively lead not only to the reduction or alleviation of poverty levels, but as well guarantee a good degree of environmental sustainability and biodiversity conservation and general LED through the adoption of responsible attitudes, practices and behaviour. This is in view of the fact that these core and enabling factors discussed hereafter would significantly contribute in making the country a potential hot-spot for sustainable tourism activities if they are properly developed and managed. 


\section{Core element}

\section{Topography and natural biodiversity}

The appellation 'Africa in miniature' is used to describe Cameroon's topographical diversity which has given rise to the rich floral and faunal diversity found in the country. The country's location at the crossroads of West and Central Africa in the gulf of Guinea has given rise to a vast floral and faunal diversity and density.

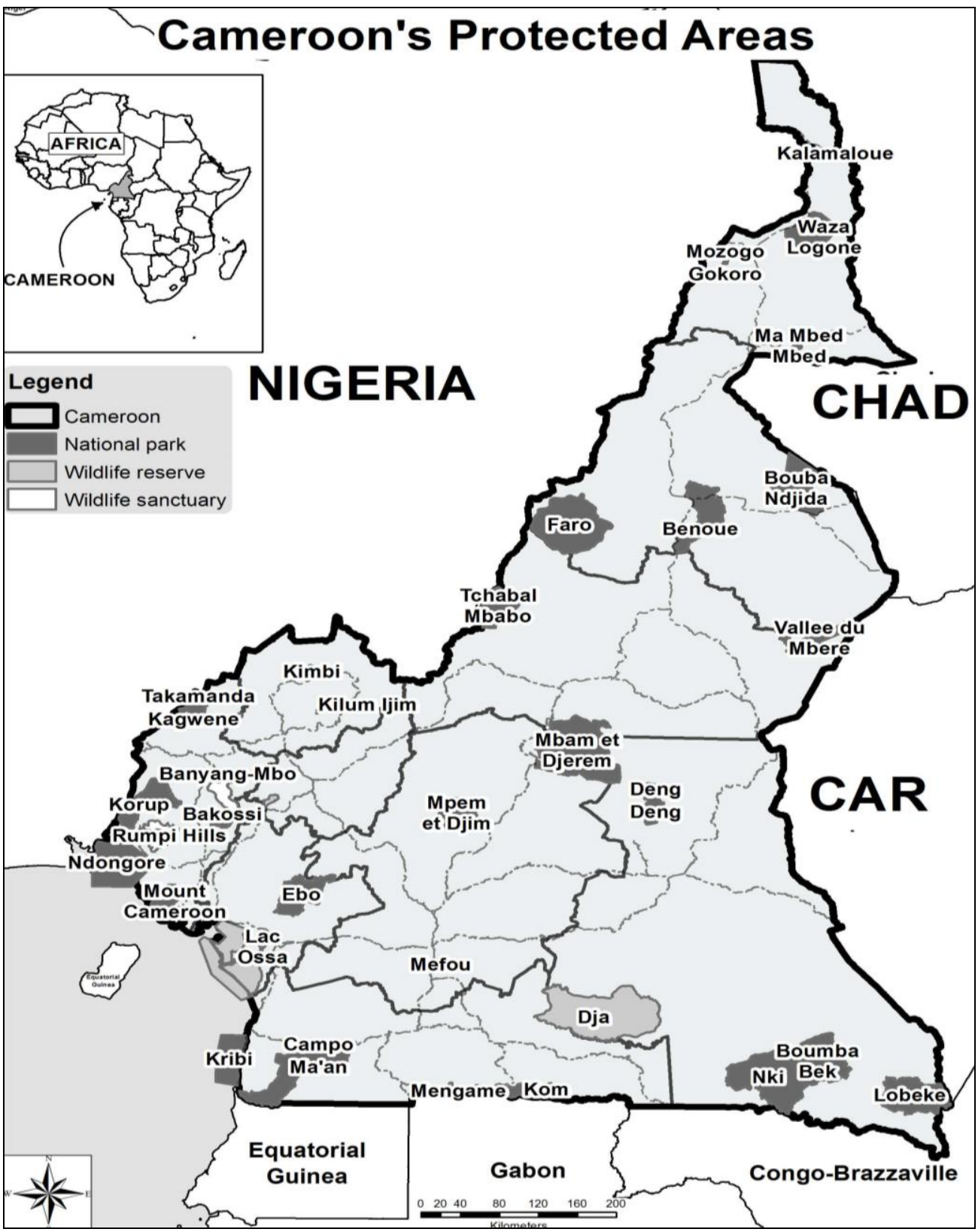

Figure 1. Geographical location of Cameroon and its protected areas (Source: Authors based on fieldwork) 
In fact Cameroon has one of the highest concentrations of endemic species on the continent apart from the island of Madagascar. Cameroon is home to 409 known mammalian species (11 of which are endemic), 849 bird species ( 7 of which are endemic), 143 species of reptiles (23 of which are endemic), close to 200 amphibian species, 542 fish species, and an estimated 9000 plant species, 156 of which are endemic (DowsettLemaire \& Dowsett, 2000; Earth Trends, 2003; MINEF, C.O.C, \& BirdLife International, 1999; Stuart et al., 1990; Vivien, 1991). It is in this regard that the World Bank and the WWF classified Cameroon as one of the 13 countries worldwide with the highest amount of biological diversity (Graf, 1997; Riley \& Riley, 2005). As a result of the realisation of this ecological diversity, work on conservation started in Cameroon as far back as during the colonial period (1884 - 1960) when the foundation of most of the parks and reserves presently found in the country such as the Kimbi River Game Reserve; the 1000 hectares Kilum Ijim Floral Sanctuary on Mount Oku (the second highest Mountain on mainland West Africa at 3,011 metres and home to one of the rarest birds in the world, the Bannerman's turaco as well as 16 endemic mammalian species) were laid down by the Germans and later by the French and English. Serious conservation work in the Kilum Ijim Floral Sanctuary only started in 1987 even though the British colonial administration started attempting to protect the reserve as far back as 1930; the Korup Forest Reserve (which is one of the last remaining undisturbed equatorial forests in the world with its rich variety of endemic flora and fauna was designated during the period of German colonisation); the 1988 revamped internationally acclaimed Limbe Botanical and Zoological Gardens (which harboured the Mount Cameroon Project in 1994 and later the Limbe Biodiversity Conservation Centre) and the Bipindi Botanical Garden were created by the German botanists Preuss and Zenker in 1892 and 1896 respectively for the study, nursing and cultivation of different plant species of the region (Eloundou, 2005).

Apart from the Korup, Kilum Ijim, Kimbi River and Mbi Crater reserves all in located in the western region of Cameroon, all faunal reserves in (francophone) Cameroon where created by orders (arrêtés) of the then French High Commissioners between 1931 and 1950 (WCMC, 1992). In the southern and eastern regions of Cameroon, include the Dja Faunal Reserve and UNESCO World Heritage Site which as early as 1930 already had some form of protection and became officially protected as a faunal and hunting reserve by Law No. 319 of 25 April 1950 by the French colonial administration before being transformed to a faunal reserve under the National Forestry Act Ordinance No. 73/18 of 22 May 1973. It was internationally recognised as a Biosphere Reserve under UNESCO's Man and the Biosphere Programme in 1981 and included in the list of World Heritage Sites in 1987 under Criteria II and IV dealing with its contribution to the evolution of mankind and its abundance of biodiversity species (UNESCO, 2008; Nyang \& Hamerlynck, 2006). Others are the 2000 $\mathrm{km}^{2}$ Lobéké National Park (which became part of the Sangha Tri-National Area, in association with the Zangha-Sangha National Park in the Central African Republic and Noabele-Ndoki National Park in the Republic of Congo as part of a commitment taken by governments of the central African sub-region to protect and ensure sustainable use of forest resources during the Yaoundé Forest Summit of 1999). The Boumba Bek Reserve, Nki National Park and the 264064 ha Campo-Ma'an National Park were created in 2000 (Government of Cameroon, 2000; Riley \& Riley, 2005; Tchakounte, 2008; Lukong, 2008).

The reduced cover of the savannah type vegetation in the north of the country which is favourable for big game viewing favoured the creation of the first six national parks in this part of the country. These include the Waza National Park and UNESCOMAB Biosphere Reserve. Located $122 \mathrm{~km}$ from Maroua in the Far North Province in the Chad depression, the vegetation in this $1700 \mathrm{~km}^{2}$ park which is the most accessible, 
famous, visited, developed and probably one of the best known of Cameroon's parks. It was created in 1934 by the French colonial administration, albeit as a hunting reserve, and it became a National Park in 1968 and a UNESCO Man and Biosphere Reserve in 1979. The park is home to a wide variety of animals including lions, elephants, hippopotamuses, rhinoceros among others as well as a large variety of birds, the most popular being the ostriches which roam the plains of the savannah; the 3,300 $\mathrm{km}^{2}$ Faro National Park which is home to a large variety of hippo colonies, black rhinoceroses, elephants and cheetahs (whose survival is actually threatened by over poaching); the Bénoué National Park which is also a UNESCO-MAB Biosphere Reserve and the Bouba Njidah National Park in the Guinea savannah belt about $150 \mathrm{~km}$ from Ngaoundéré which are famous for their elephants, giant elands and an abundance of other wildlife species (Riley \& Riley; 2005). These parks were created primarily to attract tourists. In total, four distinct topographical regions containing different varieties of flora and fauna can be mapped out in the country. These are the area around the Mount Cameroon National Park, the Korup National Park in the south/north west regions, the Campo-Ma'an / Dja National Parks and south/eastern regions Cameroon and the Waza National Park and in the 'Grand' north region. Thus whilst the south west and south eastern regions of Cameroon (North West, South West, Littoral, Centre, South and East Regions) are a potential haven for ecotourism and beach tourism development (which is gradually being developed), the northern portion of Cameroon (Adamaoua, North and Extreme North Regions) can be seen as the Mecca for safari adventurers.

Realising the significant importance of Cameroon's biodiversity and the need for its protection upon gaining independence in 1960, the tradition of creating more parks and reserves was expanded and entrenched into law. In 1974, law No. 74 / 357 of $17^{\text {th }}$ April 1974 dealing with the organisation of "state forests" was promulgated. This law fixed a quota of $20 \%$ of the national territory to be designated as protected areas. The National Assembly later on voted another law authorising the President of Cameroon to ratify the Rio Convention increasing this quota to $30 \%$ of the national territory thereby theoretically complying with the SDGs $(13,14$, and 15) linked to environmental sustainability. However, as of 2005 , only $14 \%$ of Cameroonian territory was actually under some form of protection on paper but there were plans to increase this amount to $19 \%$ especially after the approval by the World Bank to finance the Cameroon Forestry and Environmental Project in 2005 (World Bank, 2005). Presently, there are 13 national parks, 3 of which are UNESCO-MAB biosphere reserves and one a UNESCO World Heritage Site; 18 wildlife reserves, 3 wildlife sanctuaries, 16 forest reserves and protected areas, 9 cloud (mountain) forest sites in the country (Table 1). This is in addition to the $402 \mathrm{~km}$ of coastline with pristine beaches near the foot of Mount Cameroon in Limbe (South West Region) and at the entrance of the equatorial forest around Kribi and Campo (South Region) as well as the diversity and multiplicity of customs and traditions manifested in architecture, dressing, music, song and dancing most especially in the Western and Northern Regions of Cameroon.

\begin{tabular}{|c|c|c|}
\hline Protected Areas & Number & Surface area (ha) \\
\hline National Parks & 11 & 2577930 \\
\hline Faunal Reserves & 6 & 702995 \\
\hline Synergetic Zones & 35 & 3083750 \\
\hline Faunal/Floral Sanctuaries & 2 & 132000 \\
\hline Zoological Gardens & 2 & 4,07 \\
\hline TOTAL & 56 & 6496499,07 \\
\hline
\end{tabular}

Table 1. National parks, reserves and protected areas in Cameroon (Source: Ministry of Forestry \& Fauna - MINFOF, 2007) 
With its rich and abundant biodiversity, LED around these parks and sites can be promoted, if different forms of community based sustainable tourism development ventures are introduced, and if successfully managed and monitored, these ventures could go a long way in attaining the objectives of poverty alleviation and environmental sustainability set out in the SDGs.

\section{Enabling elements \\ Proximity to Europe}

Considering the fact that Cameroon is only about six hours away from most European countries by air, the country could have been profiting as a winter sun destination just as the likes of the Gambia and Senegal or a safari paradise just like Kenya, Tanzania or Botswana for example. This is however, not the case owing to high air travel related costs. While strides have been made interms of the number of airlines operating in the country (from 8 companies in 2009 to 30 as at 2015 as available data shows) (see Ncham, 2009; Business in Cameroon, 2015), air transport to Cameroon is still considered a costly affair as ticket prices, coupled with lack of low-cost no-frills airline operators and charter flights, excessively high airport taxes make the destination an expensive one to visit.

\section{Adventure/discovery factor}

Cameroon as far back as the colonial period has always been a region of fascination to adventurers. It is while living here during their colonial expeditions and adventures that popular early 20 ${ }^{\text {th }}$ Century novelists such as Gerald Durell collected tropical plant and animal specimens and had inspiration for his best selling novel The Bafut Beagles. This fascination has continued up till recent times drawing big screen movie directors to use some of its natural parks as settings to some of their movies such as Hudson's (1984) Greystoke: The Legend of Tarzan, Lord of the Apes featuring Andie MacDowell and Christopher Lambert or Antoine Fuqua's The Tears of the Sun in 2003 featuring Bruce Willis and Monica Belluci amongst others set in Nigeria and Cameroon. As such the varied topography and vegetation most of which has resisted the impacts of development and civilisation due to its remoteness sometimes very difficult terrain limiting accessibility offers a very fruitful environment for tourists who are out for adventure and discovery in all parts of the country. This adventure and discovery element makes Cameroon which according to Butler's (1980) tourism area life cycle is still somewhere between the involvement and development stage. At the moment it is mostly visited by a variety of tourists ranging from what Plog (1974) and Cohen (1972) describe as allocentric travellers and explorers respectively, to near venturers and centric venturers.

\section{Language and cultural diversity of the people}

Though three main linguistic groups are identified in Cameroon; the Bantuspeaking peoples of the south, the Sudanic speaking peoples of the north and the semiBantu speaking peoples in the west, Cameroon's ethnic composition is varied and diverse with more than 250 distinct ethnic groups speaking more than 270 languages and having as many distinct cultures and traditions manifested in music, song, dance, clothing, and nutrition. This makes it one of the countries in the world with the highest number of ethnicities, languages and cultural diversity (Paden \& Soya, 1970; Benneh, 2008; Ilies et al., 2017; Ilies et al., 2009). The principal ethnic groups consist of the Cameroon Highlanders who account for $31 \%$ of the population, the Equatorial Bantu for 19\%, the Kirdi for $11 \%$, the Fulani for $10 \%$, the North-western Bantu for $8 \%$ and the Nigritic for $7 \%$, other African 13\%, and non-African less than 1\%. In spite of the multiplicity of ethnic languages, English and French are the official languages with French being the most spoken (Benneh, 2008), enabling easy communication between locals and tourists. 


\section{MATERIALS AND METHODS}

Primary data for this research came from in-depth semi-structured interviews/ discussions that were conducted with 20 tourism industry stakeholders; 8 from the private sector and 12 from the public sector organisations in Cameroon in 2017 and 2018. Primary data was also generated by the researchers from a total of seven field visitations that were undertaken to various sites that were considered as existing tourism developmemt products, including those with a strong potential. Using a purposive snowball sampling technique (Mason, 2002), public sector stakeholders from Cameroon's Ministry of Tourism and Leisure, and national park conservators which are all stateowned on the one hand and private sector stakeholders made up of representatives of community based tourism organisations, home-based tour/hotel operators and local community representatives on the other hand were targeted to take part in the study.

The in-depth semi-structured interviews and discussion techniques were considered appropriate for the current study as it allows for access to rich and personal data and the ability to understand the stakeholder's context and motivations linked to the study objective. Particularly, the opportunity for the researchers to access the "interviewees' thoughts, reflections, experiences, memories, understanding" (Morris, 2015: 5) of tourism and LED, linked to SDGs in Cameroon was a major motivation. In addition, the lack of upto-date secondary data sources and accurate statistics of tourism development in Cameroon (Tichaawa, 2017; Harilal et al., 2018) and the interviewing strategy adopted meant that the researchers were able to elicit as much information as possible from the respondents on the topic. The interviews lasted for between 30 and 60 minutes. Interviews were conducted on a face-to-face basis at a predetermined location of choice selected by the interviewee. The interviews were digitally recorded and later transcribed vabatim. Suplimentated by fiedtrip notes and observations, the content analytical technique was used to generate the results from the interviews, which are presented next.

\section{RESULTS DISCUSSIONS}

In spite of possessing the natural elements favouring the development of an ecologically sustainable tourism industry capable of alleviating poverty within communities in the Central African sub-region and Cameroon in particular, and in spite of the commitment of some governments of the region to prioritise the development of the tourism industry as one of the means of stimulating local economic growth in areas devoid of other natural (e.g. minerals) resources and industries and thereby attaining the SDGs linked to poverty alleviation and environmental sustainability, it is becoming increasingly difficult to see how countries in the sub-regionin general and Cameroon in particular will attain these goals by the 2030 target date. Analysis of data collected during the field work i.e. interviews, observations and secondary data revealed the existence of some core and general challenges which made LED and the attainment of the other two SDGs through tourism a far fetched reality. Some of the principal challenges included the lack of finance leading to the non implementation of park management plans, shortage of park management staff, poor maintenance and upkeep of tourist sites, inexistent or maraud service infrastructure, non implementation of general tourism policy framework, conflict of interest between various stakeholders and government departments, as well as slow pace of professionalisation of the tourism sector.

\section{Principal challenges}

\section{Lack of Finance}

The absence of or limited nature of financial resources for investment, infrastructural development and maintenance and human resource management was 
considered to be the primordial problem by all tourism industry stakeholders in Cameroon and this contributed to:

\section{Absence of a sustainable tourism development and management policy}

The Cameroon Tourism Sectorial Development Plan drawn up in 2005 which outlined the some of the potential areas and types of tourism (most notably ecotourism) which had to be consolidated and developed as well as the means of undertaking these developments in various parts of the country has still to date remained only on paper with very few of its recommendations ever having been put into practice. This is the same situation with Cameroon Tourism Marketing Plan drawn up in 2002 (which outlined a strategy for the marketing of the country as a tourism destination) with the technical and financial assistance of the Commonwealth. Its recommendations have also to date been implemented only on an adhoc basis. These issues do arise because of the absence of the concise and precise tourism policy in Cameroon (see Harilal et al., 2018) coupled with the absence of an independent national tourism board to oversee the general development and management of the country's tourism industry. The effects of the absence of a clearly defined tourism policy and strategy coupled with the absence of a national tourism board (Kimbu \& Ngoasong, 2013) has led to the industry being in a disorganised state with very little cooperation and coordination between various branches of the industry on the one hand and other sectors of the economy in general leading to conflicts of interest between the various stakeholders involved.

Conflicts of interest between various stakeholders and government policies

Persistent conflicts of interest between the various ministerial departments as well as between public and private stakeholders within Cameroon's tourism industry accounted for the limited contribution of tourism to LED and in the process hampered the attainment of the SDGs related to economic growth and decent work, poverty eradication and environmental sustainability. Due to the ever increasing and changing developmental plans of the government, decisions are sometimes made which stand in direct contradiction to these goals. In the past, most of these conflicts arose from the infringement by lumbering companies who had been granted logging concessions near national parks. Some took it on themselves to log right into the parks but this attitude according to one of the interviewees is presently being brought under control thanks to the decisive action of the present Minister of the Environment and Forest who has "waged a campaign against illegal logging (and poaching) in protected areas of the country" as well as the change in the attitudes of a few logging companies who have joined forces with the conservation agencies aimed at environmental protection. Companies caught logging on protected areas are sometimes imposed severe penalties and some have had their exploitation licences revoked. On the other hand however, there are certain areas where the national interest has superseded interest of conservationists, be they from the government or from national and international NGOs. This was the case with the decision on construction of the World Bank sponsored Chad Cameroon pipeline project (which passes through the Campo Ma'an National Park though care was taken to avoid destroying the Deng Deng Forest Reserve which is one of the rare hardwood forests in Africa) completed in 2003 (IFC.org, 2003). It is presently the same situation with the recently launched Kribi deep sea port and gas terminal project where the government and local inhabitants opted for the construction of the above infrastructure instead of the creation of a marine park in the region citing the economic advantages which could accrue from the realisation of this project in the region (PAK, 2018; Bainkong, 2009).

This scenario was likely to be replayed with the construction of the Lom Pangar Dam and hydro electric power station in the Eastern Region which will not only flood about $318 \mathrm{~km}^{2}$ of the Deng Deng Forest Reserve but also parts of the Lom Pangar Reserve as well as the construction of the Mve-Ele hydroelectric dam in the Southern region of 
Cameroon (Ngala, 2009). Though the construction of these two dams when completed will significantly boost the country's deficient electricity output and is expected to increase economic activities (leading to the attainment of SDGs 1 and 8) (World Bank, 2018), vast areas of the parks and reserves within the area will be flooded with the result that floral and faunal species some of which are endemic will be lost for ever as well as displace many local communities from the habitats impacting on their wellbeing (SDG 3). These activities will lead to an influx of people into the region, worsening the spectre of illegal logging, poaching and fishing, and obviously generate associated risks like the spread of diseases. The same situation also holds true for the granting of multiple mining concessions by the Ministry of Mines within already designated national parks to multinational companies for the exploration and eventual exploitation of minerals such diamonds, gold, bauxite, nickel and cobalt among others. Logging and mineral exploration and exploitation activities are presently taking place within parts of the Boumba-Bek and Lobéké National Parks and according to the WWF Cameroon these activities will all have negative consequences to the flora and fauna of these parks because the methods of exploitation are not at all compatible with the objective of protecting of the biodiversity in these parks (SDG 15) (Elvido, 2009). Even though jobs will be generated once the exploration phase of mineral mining starts, if not well planned the consequences could be disastrous to the communities living around these sites, the environment and the biodiversity in the long term. There are thus persistent conflicts of interest between the various stakeholders involved in the country's tourism industry but national interest always takes pride of place over environmental conservation and sustainability issues which even though taken into consideration when drawing up management plans often end up being relegated to the background. All these actions make attaining SDGs 1 and 2 a distant reality.

\section{Non implementation of park management plans}

Since 2002, Park management plans have gradually become the order of the day in all of Cameroon's main national parks. However, the effective implementation of the projects found in them leaves much to be desired. Before the advent of these plans, emphasis since the late 1990s had been placed by the government in the integration of development of ecologically sustainable tourism ventures with national park conservation. Conservation and tourism development near or within parks during this period was mostly realised thanks to the technical and financial assistance of international non-governmental organisations such as the World Wide Fund for Nature (WWF), German Technical Cooperation Mission (GTZ), Dutch Development Organisation (SNV), and the UK Department for International Development (DFID). This started off with the Korup Project in the South West region of Cameroon sponsored primarily by the WWF, the EU and the UK DFID. The main aims of the project were to achieve conservation and protection of the biologically important Korup National Park while integrating the conservation and protection goals with the development the development goals of the local communities (Kimbu \& Ngoasong, 2013; Kimbu, 2010; Ilies et al., 2017, 2018b; Gozner \& Avram, 2010). In addition it aimed to achieve a well-functioning and well-managed park which the local communities prized and which provided benefits to them in terms of natural resources and income from tourism and employment.

The project lasted from 1997 to 2002 during which conservation work was done in the park and the ecotourism initiatives were also introduced, hiking trails were opened within the park and camps were also constructed in addition to a guest house in the town of Mundemba at the entrance to the park. The local populations some of whom were former hunters and poachers were also actively engaged and many employed and trained as 
ecoguides, eco-monitors and porters. However when the project wrapped up in 2002 at the end of the contract, funding dried up and the Cameroonian government was not able to continue with some of these projects even though their continuation had been envisaged in the Korup Park Management Plan which was drawn up at the end of the Korup Project. As a result, the most of the infrastructure set up fell into disrepair and the some members of the community who had been employed became redundant and went back to hunting and poaching with very negative consequences for the flora and fauna of the park.

The same was the situation with the Mount Cameroon Project which was set up and funded by the German Development Mission (DED) and the GTZ. The aim was the foster the conservation of the floral and faunal resources on Mount Cameroon by reducing the pressure on it from the local communities who were to be actively and profitably engaged in this conservation venture by being offered income generating activities centred around conservation and eco tourism development. The project lasted from 1998 - 2007 during which time former hunters and forest product gatherers from the surrounding mountain communities were employed and retrained as guides, porters and farmers. The project was a success until the departure of the GTZ and DED team when management divergences started cropping up leading to some of the porters and guides to return to their past preoccupations. In addition since the end of foreign assistance, maintenance of some of the infrastructure (trails and camps) leading up to the mountain has virtually come to a standstill and most are in a state of decay. Visitor numbers to the mountain which until 2007 had been steadily increasing is now declining. It was thus very evident that even though the government has made it a priority to include the sustainable development of ecotourism activities around most of Cameroon's nature parks and reserves, in principle it remains only in theory due to the lack of financial resources to execute these goals in the field. Without external help from foreign donors, (as is presently the case with the KudoZombo Project in the Campo-Ma'an National Park sponsored by the WWF), most of these plans will never see the light of day. The Ministry of Tourism and Leisure itself has one of the smallest budgets (6.3 billion francs $\mathrm{CFA}^{1}$ in 2017) (Ivaha, 2017) when compared to all other ministries and half of this is used to service the administrative costs alone.

\section{Human resource deficiencies in management and technical staff}

Environmental sustainability and conservation which is directly linked to SDGs 13.14, and 15 can only be achieved if the appropriate service personnel needed to carry out tasks related to conservation and ecotourism development are in place. Unfortunately this is not the case with most of Cameroon's parks, reserves and other protected sites. The presence of only two professional schools in the country for the training of senior forestry and wildlife engineers and mid-level forestry technicians and only two main institutions for training management staff in the tourism and hospitality industry (receiving only a limited number of students annually) means that there is a shortage of well trained and skilled professional staff needed to oversee and effectively coordinate the day to day management of the different tourism activities, natural parks and sites in the country. In the Korup National Park for example there are only 3 mid level technicians and 20 ecoguards who patrol and do ecological monitoring in the park. This is lesser than the number which was stipulated in the Park Management Plan which provided for 36 ecoguards and the when the IUCN ratio of ecoguards to park surface area is taken into consideration. It is the same situation for example in the Kimbi River Game Reserve, the Dja Faunal Reserve and the Faro National Park with their large variety of flora and fauna whose survival is actually threatened by over poaching from poachers a good number of whom come from the neighbouring Central

${ }^{1} 1$ Euro $=655.957$ CFA Francs 
African Republic and Chad and from far away Sudan. Illegal lumber exploitation and mineral prospections from companies which have concessions near these parks was also identified as a serious threat by the interviewees (Musa, 2012; Riley \& Riley, 2005).

\section{General challenges}

Some of the general challenges which emanated from the interviews and field observations and which are also contributing in limiting the eventual attainment of the SDGs related to poverty eradication through tourism development and environmental conservation in Cameroon included the existence of inadequate marketing and publicity due to the lack of funding to attend tourism fairs and exhibitions as well as carry out serious marketing campaigns.This meant that the country was not very well known as such was still not considered as a tourist destination according to UNWTO standards; improper behaviour of immigration and public security officials at the airports and on highways leading to complaints of harassment by some tourists; limited government support to small business operators in the sector which meant they had to fend for themselves and were incapable of raising the necessary collateral security needed grow their businesses and to go into partnerships with international tour operators and neither could they take part in international tourism fairs which served as one of the best avenues to market their products, limited information and technology (ICT) skills enabling them to make muse of ICTS in marketing their products and getting visibvility, (Kimbu, 2011a) poor government taxation/registration policies caused by unnecessary bureaucratic bottlenecks leading to increased costs for the local operators and making their businesses unsustainable (Ngoasong \& Kimbu, 2016; Kimbu \& Ngoasong, 2016). Additionallly, another major issue hampering the development of tourism and the marketablility of Cameroon as an attractive destination could be attributed to two major geopolitical situations that Cameroon has experienced in recent times. Firstly, terrorist activities perpetrated by the Boko Haram group in the northern parts of the country, which is home to its best known national parks and safari game reserves (e.g. the Waza and Bouba Ndjida national parks) (International Crisis Group, 2016) means that very few (inter)national tourists venture to the north of the country. Secondly, the domestic tourism market, especially in the North West and South West Regions of the country has since 2016 witnessed a slump in activities due to the ongoing Anglophone crisis making these regions less attractive to visitors and seriously impacting on the business activities of the tourism and other industries. The perceptions of such political unrest and its spill over effects have been noted to affect tourism performance in the past, due to the downturn in the economic activities linked to both domestic and international tourism they are likely to cause (International Crisis Group, 2018) This could also contribute to limiting the industry's contribution to attaining the SDGs and LED in Cameroon.

\section{Contribution}

The absence of an effective tourism framework coupled with the lack of finance for human resource development as well as the development and promotion of the industry means that tourism in Cameroon is still not considered as a full time profession (Kimbu \& Ngoasong, 2016). Many private operators who work in the sector consider it as a part time business with other concurrent businesses they manage by the side. It is the same case with individuals from the local communities who consider the sector as not being sustainable enough for them to live off it and maintain their families from their employment in the sector. It is as a result of this that when ecotourism ventures are initiated in the communities (Mount Cameroon National Park, Korup National Park or Belo Rural Development Project for example), the amount of enthusiasm shown by the locals (apart from the Northern Region of Cameroon which already had safari and 
synergetic tourism activities being practised there as far back as the 1960s and are thus used to tourism) is always very low due to the fact that the notion of tourism is still relatively new to most of them. As such the benefits of the training courses which often accompany the introduction of these projects even though attended are short lived. This is due to the fact that in the long run when participants trained (in such disciplines as guides, porters, guards) realise that the proceeds from tourism are not immediate but rather take time in coming and not as not regular due to the fact that the tourism season in Cameroon lasts from November to April, the general tendency is for them return back to their past preoccupations (mainly poaching and illegal collection of forest products) which has disastrous consequences for the environment. The result of this is that in comparison to other countries such as Botswana, Kenya or Senegal where up to $4 \%$ of the labour force is directly employed in the travel and tourism industry which in turn contributed more than $9 \%$ of the GDP of these countries in 2017, in Cameroon the WTTC estimated that $2.6 \%$ of total employment in the country came from direct tourism industry jobs and $6 \%$ of total national employment was generated by the travel and tourism economy as a whole. In addition the travel and tourism industry in Cameroon directly contributed only $3.2 \%$ to the GDP in 2017 (WTTC, 2018). Thus an integrated LED framework aimed at overcoming the above mentioned challenges and which makes sustainable use of the existing biodiversity available in the different communities will have to be instituted if the SDGs of poverty alleviation will have to be attained (Figure 2).

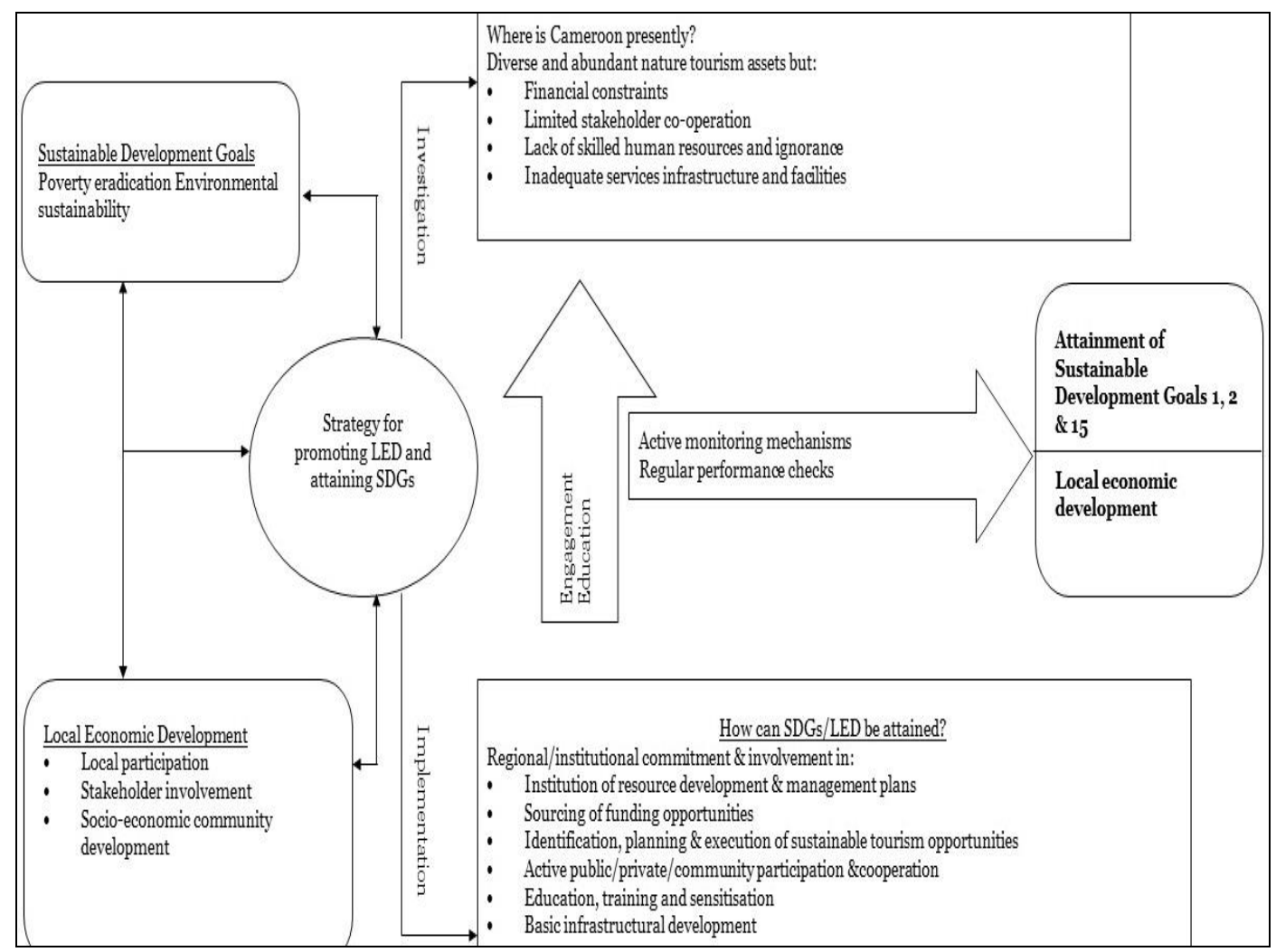

Figure 2. Framework for the attainment of Sustainable

Development Goals $(1,2,15)$ \& LED through tourism development in Cameroon 
In order to guarantee the effective utilisation of Cameroon's tourism potential as one of the tools in attaining the SDGs of poverty alleviation and environmental sustainability and therefore LED, tourism would first and foremost have to be considered by the public and private sector as an industry with equal standing to other industrial sectors in Cameroon capable of generating revenue and contributing to the GDP, creating jobs and improving the standards of living of the communities.

If this reality is recognised and accepted by the government, the Ministry of Tourism and Leisure and related ministries will have to be provided with a budget which will enable it to carry out the necessary reforms (setting up professionnal services, staff recruitment and training, marketing and publicity campaigns) and implement measures guaranteeing the effective take off of the industry in the country. This at the moment is however not the case.

It would be imperative for the government and committed private sector stakeholders to carry out education and sensitisation campaigns through out the country and most especially in areas of existing and potential tourism development in order to successfully introduce tourism to the communities as a tool for local economic development, poverty alleviation and environmental protection in Cameroon. The inhabitants will have to be sensitised and educated on the economic advantages that the sustainable development and management of tourism resources can bring to their communities as well as made aware of the fact that tourism development is a process that takes time before profitability sets in. Local communities and minority groups will also have to be empowered and given the freedom to control and manage the sustainable tourism projects after they must have received initial training from capacity building workshops and institutions set up by the government in conjunction with other stakeholders with the necessary expertise and know-how (Ngoasong \& Kimbu, 2016; Kimbu \& Ngoasong, 2016). Without the necessary training, the community members will not be able to manage these structures and they will gradually fall into disrepair as was observed in the Korup National Park. Another factor to be taken into consideration will be that of active stakeholder collaboration and cooperation. All tourism industry stakeholders will have to effectively work together in the development of the industry which should be placed under the supervision of an autonomous national, regional and local tourism boards (bringing together representatives of public and private sector stakeholders) that will have to be created (Kimbu \& Ngoasong, 2013). One of the initial tasks of this board will be to come up with a practical and financially sustainable framework for tourism development and management in the country as well as assume responsibility for the professionalisation of the industry.

The government on its part in addition to creating the basic enabling infrastructure (transportation, health, security which at the moment are lacking in most of Cameroon's tourism sites) necessary for development in the country (Kimbu, 2011b) will have to liberalise the sector and reduce the administrative bottlenecks as well as give tax incentives to potential investors. These measures would encourage investments from private sector individuals at the national and international levels who up till now have been shied away by the bureaucracy, lack of incentives and the general absence of a conducive environment for tourism development in the country.

In addition, the government should engage in a serious and continuous marketing campaign in the potential source markets of Europe and North America where very little has been done up till now as regards marketing and promotion (Kimbu, 2011a). This marketing could take place in the form tourism trade fair attendances in reputed fairs of Berlin, Paris and London for example. 


\section{CONCLUSION}

The geographic location of the country, the rich and varied topographical, floral and faunal biodiversity coupled with the multi-linguistic and cultural diversity of the country provide the primary components necessary in making Cameroon a very fertile terrain for the development of a sustainable tourism industry capable significantly contributing to the realisation of the SDGs linked to ending poverty (SDG 1) and promoting environmental sustainability (SGDs 14 and 15) leading to local economic development (SDG 8). However a lot of work still has to be done with regards to coordinating and providing the necessary services and infrastructures which will harness these potentials and make them profitable to all stakeholders engaged and guarantee that future generations still get to profit from them. It is only when this foundation has been laid and constant monitoring ensured that it will be possible to look positively into the future and be certain that tourism will be a significant arsenal in the fight against poverty and environmental sustainability in Cameroon. In addition a blueprint that aims to mobilise all stakeholders including those in the government, the private sector and the community, to work in synergy with the view to make the tourism sector in the country a catalyst for positive change for citizens is of essence. The research examined the present level of tourism development in some of the national parks in Cameroon. However, focus was placed mainly in some of the parks located in southern half of the country and as such, it would be preposterous to conclude that these same situation holds true for the north of the country (home to the famous Waza and Benoué National Parks, both MAB reserves) which as far back as the 1960s was already well known internationally (frequented mainly by French visitors) for some of its excellent photographic nature safari and synergetic tourism sites. Future research could look at the effects tourism has had over the decades in this part of the country and its impact on the socioeconomic development of this region as well as the consequences on the environment. It could also examine the role other forms of tourism such as cultural tourism (already being practiced in some parts of the country) can contribute to the attainment of these goals.

\section{Acknowledgement}

A preliminary version of this paper was presented at the Advances in Tourism and Hospitality Marketing and Management conference in Istanbul Turkey in 2011 and published in the conference proceedings. The University of Johannesburg is thanked for part of the funding provided for the accomplishment of the study.

\section{REFERENCES}

Bainkong, G. (2009). Kribi deep seaport: Construction begins next year. Retrieved August 24, 2015, from Camerounlink Web site: http://www.camerounlink.net/fr/news.php?SessionID=Z4EP3LXW4RSQN5 CDJUG4JMOQZF7MYZ\&cl1=1\&cl2=\&bnid =0\&nid $=48115$.

Bakker, M., \& Messerli, H.R. (2017). Inclusive growth versus pro-poor growth: Implications for tourism development. Tourism and Hospitality Research, vol. 17, no. 14, p. 384-391.

Benneh, G. (ed.). (2008). Cameroon. Encyclopaedia Britannica. Retrieved February 19, 2008 from Encyclopaedia Britannica website: http://www.britannica.com/eb/article-9110775/Cameroon.

Butler, R. (1980). The concept of the tourism area cycle of evolution. Canadian Geographer, vol. 24 , no. 4.

Christie, I., Fernandes, E., Messerli, H., \& Twinning-Ward, L. (2014). Tourism in Africa: Harnessing tourism for growth and improved livelihoods. Washington DC: World Bank.

Cohen E. (1972). Towards a Sociology of International Tourism. Social Research, vol. 39, p. 164-182.

Dowsett-Lemaire, F. \& Dowsett, R.J. (2000). Birds of the Lobéké Faunal Reserve, Cameroon, and its regional importance for conservation. Bird Conservation International, vol. 10, p. 67-87.

Elvido, S.C. (2009). Biodiversité : L exploitation minière menace les aires protégées. Retrieved August 26, 2018, from CamerounLink website: http://www.camerounlink.net/fr/news.php? 
Sustainable Development Goals and Socio-economic

Development through Tourism in Central Africa: Myth or Reality?

Harilal, Tichaawa, T.M., \& Saarinen, J. (2018). "Development without policy”: Tourism and Planning Research needs in Cameroon, Central Africa. Tourism Planning \& Development, https://doi.org/10.1080/21568316.2018.1501732.

Gozner, M., \& Avram, M. (2010). The situation of the natural reservation from the Territorial System Albac Arieseni. Analele Universităţii din Oradea, Seria Geografie, Tom XX, Editura Universităţii din Oradea.

Gozner, M., Josan, I., Baias, S., \& Măduta, F.M. (2016). The Religious Attractions - An Expression of Authenticity in the Territorial System Albac - Arieșeni and Alba County (Romania). GeoJournal of Tourism and Geosites, Year VIII, Volume 15, Oradea-Gdansk, Romania-Poland, Editura Universităţii din Oradea.

Graf, M. (1997). Conservation of forests reserves around Akwaya. Report of the Appraisal Mission. Eschborn/Fs 08(07), 24-41.

Ilies D. C., Blaga L., Hodor N., Josan I., \& Gozner M. (2009) „Estimation Of The Geomorphostructures With Geomorphosite Valence In The Northern Part Of The Hunedoara County (Western Romania)”. Analele Universităţii din Oradea, Seria Geografie, Editura Universităţii din Oradea; http://journals. indexcopernicus.com/karta.php?action=masterlist\&id $=3951$.

Ilieș A., Wendt, J. A. Ilieș, D.C., Herman, G.V., Ilieș M. \& Deac, A. L. (2016), The patrimony of wooden churches, built between 1531 and 2015, in the Land of Maramureș, Romania. Journal of Maps, Volume 12, 2016, pp 597-602 - Issue sup1 (http://dx.doi.org/10.1080/17445647.2016.1243075).

Ilies A., Hurley P. D., Ilies D. C., \& Baias S. (2017). Tourist animation -a chance adding value to traditional heritage: case studys in the Land of Maramures (Romania). Revista de Etnografie şi Folclor, New Series 1-2.

Ilies D. C., Buhas, R.C., Ilies M., Ilies A., Gaceu O., Pop A. C., Marcu F., Buhas S. D., Gozner M., \& Baias S. (2018 a) Sport activities and leisure in Nature 2000 protected area -Red Valley, Romania, Journal of Environmental Proection and Ecology, 19, no 1, 367-372, (http://www.jepe-journal.info/journal-content/vol-19-no-1.

Ilieș, D.C., Herman, G.V., Ilieș, A., Baias, S., Dehoorne, O., Buhaș, S.D., Dumbravă, R., Buhaș, R., Josan, I., Carțișet, H., \& Ungureanu, M. (2017). Tourism and Biodiversity in Natura 200o Sites. Case Study: Natura 2000 Valea Roșie (Red Valley) Site, Bihor County, Romania. Études caribéennes, (37-38).

Ilieș, D.C., Onet, A., Wendt, J. A., Ilies M., Timar, A., Ilieș A., Baias S., \& Herman, G.V. (2018 b). Study on microbial and fungal contamination of air and wooden surfaces inside of a istorical Church from Romania, in Journal of Environmental Biology, vol 39/6, pp.980-984 (http://www.jeb.co.in /journalissues/ 201811_nov18/papero6.pdf).

Hudson, H. (1984). Greystoke: The Legend of Tarzan, Lord of the Apes. (DVD). Los Angeles: Warner Brothers.

Ivaha, G. (2017). Cameroun-Budget: Ces administrations qui plombent le Budget de l'Investissement Public. Retrieved October 04, 2018, from http://www.cameroon-info.net/article/cameroun-budget-cesadministrations-qui-plombent-le-budget-dinvestissement-public-298704.html.

Kimbu N. A. (2017). Cameroon In: Lowry L (eds.). The SAGE International Encyclopedia of Travel and Tourism, pp. 212-213 SAGE Publications, Inc.

Kimbu, N. A. (2011a). The challenges of marketing tourism destinations in the Central African sub-region: The Cameroon example. International Journal of Tourism Research, vol. 13 no. 4, p. 324-336.

Kimbu, N. A. (2011b). The role of transport and accommodation infrastructure in the development of eco/nature tourism in Cameroon. Tourism Analysis, vol. 16, no. 2, 137-156.

Kimbu, N. A. (2010). Sustainable tourism development management in Central Africa: A case study of the tourism industry in Cameroon. Doctoral dissertation. Nottingham: Nottingham Trent University.

Kimbu, N. A., \& Ngoasong, M. Z. (2013). Centralized decentralization of tourism development: a network perspective. Annals of Tourism Research, vol. 40, p. 235-259.

Kimbu A. N., \& Ngoasong, M.Z. (2016). Women as vectors of social entrepreneurship. Annals of Tourism Research, vol. 6o, p. 63-79.

Lukong, P.N. (2008). Cameroon: America to Support Cameroon's Ecotourism. Cameroon Tribune, Yaoundé. Retrieved February 07, 2018, from: http://allafrica.com/stories/200801100728.html.

Mason, J. (2002). Qualitative researching. London: Sage.

Morris, A. (2015). A practical introduction to indepth interviewing. Sage, London.

Musa, T. (2012). Poachers kill 200 elephants in Cameroon killing spree. Retrieved October 16, 2018 from Reuters website, https://www.reuters.com/article/us-cameroon-elephants/poachers-kill-200-elephants-incameroon-killing-spree-idUSTRE81G10720120217.

Ncham, V.K. (2009). Cameroon Airlines Guide. Douala: Flight Movement International.

Ngala, K.C. (2009). Cameroon: Fears for forest as dam construction begins. Limbe: Retrieved August 04, 2018, from The Post Online website: http://www.postnewsline.com/2009/08/.

Ngoasong, M. Z. \& Kimbu, A. N. (2016). Informal microfinance institutions and development-led tourism entrepreneurship. Tourism Management, vol. 52, p. 430-439.

Nyang, M. \& Hamerlynck, O. (2006). Mission Report: Rapport de Suivi de l'État de la Conservation de la Réserve de Faune de Dja en Republique du Cameroun, Site de Patrimoine Mondiale, 23-30 Juin 2006. Paris: UNESCO, IUCN. Retrieved January 31, 2018, from UNESCO Web site: http://whc. unesco.org/en/list/407/documents/.

Paden, J.N. \& Soja, E.W. (1970). The African Experience. Evanston: Northwestern University Press. 
Plog, S. (1974). Why destination areas rise and fall in popularity. Cornell Hotel and restaurant Quarterly, vol. 15, p. 13-16. Riley, L. \& Riley, W. (2005). Nature's Strongholds: The World's Great Wildlife Reserves. Princeton: Princeton University Press.

Rogerson, C.M. (2002). Tourism-led local economic development: the South African experience. Urban Forum, vol. 13, p. 95-119.

Rogerson, C.M. (2015). 'Local economic development', in J.D. Wright (ed.). International Encylopedia of Social and Behavioral Sciences Vol. 14, Oxford, UK: Elsevier, p. 279-283.

Rogerson, C.M. (2016). 'Climate change, tourism and local economic development in South Africa', Local Economy, vol. 31, no. 1-2, p. 322-331.

Rogerson, C.M. \& J.M. Rogerson. (2010). 'Local economic development in Africa: global context and research directions', Development Southern Africa, vol. 27, p. 465-480.

Rogerson, C.M. (2006) Pro-Poor local economic development in South Africa: The role of pro-poor tourism, Local Environment, vol. 11, no 1, p. 37-6o.

Stuart, S.N., Adams, R.J., \& Jenkins, M.D. (1990). A Contribution to the Biodiversity Conservation Strategy Programme. Gland Switzerland: IUCN.

Tichaawa, T. M. (2017). Business tourism in Africa: The case of Cameroon. Tourism Review International, vol. 21, p. $181-192$.

Tchakounte, A. (2008). Janet E. Garvey au Parc de Campo-Ma'an. Retrieved January 15, 2018, from Cameroon Tribune Web site: http://www.cameroon-tribune.net/article.php?lang=Fr\&oled=j15012008\&idart=7941.

Vivien, J. (1991). Faune du Cameroun, Guide de Mammifères et Poisson. Yaoundé: GICAM and Coopération Française.

*** British Broadcasting Corporation (BBC). (2008). Country Profile: Cameroon. Retrieved January 21, 2016 from BBC Web site: 2008http://news.bbc.co.uk/2/hi/africa/country_profiles/1042937.stm.

*** Business in Cameroon. (2015). Air Transportation: A battle for the skies. Retrieved 10 October, 2018, from https://www.businessincameroon.com/pdf/BC29.pdf.

*** Earth Trends. (2003) Biodiversity and protected areas - Cameroon. Retrieved August 20, 2017 from: http://earthtrends.wri.org/pdf_library/country_profiles/bio_cou_120.pdf.

*** Eloundou, E.D. (2005). Vestiges historiques et préservation de la mémoire coloniale Allemande au Cameroun. In S. Michels, \& A-P Temgoua. (eds.). The Politics of Colonial Memory in Germany and Cameroon: Proceedings of a Conference in Yaoundé, October 2003. Berlin: LIT Verlag.

*** Government of Cameroon. (2000). Decree Creating the Campo Ma'an National Park. Retrieved March 04, 2018, Cameroon Government Web site: http://www.spm.gov.cm/showtexte.php?idtexte=256\&lang=en.

*** International Crisis Group. (2018). Cameroon's Anglophone crisis: How the Catholic Church can promote dialogue. Briefing No 138/Africa. Retrieved October 04, 2018 from https://www.crisisgroup.org/africa/centralafrica/cameroon/b138-cameroons-anglophone-crisis-how-catholic-church-can-promote-dialogue.

*** International Crisis Group. (2016). Cameroon: Confronting Boko Haram. Report No 241/Africa. Retrieved October 04, 2018 from https://www.crisisgroup.org/africa/central-africa/cameroon/cameroon-confronting-boko-haram

*** IFC (2003). Chad-Cameroon Pipeline Project. International Finance Corporation. Retrieved 16.10.2018, fromhttps:// www.ifc.org/wps/wcm/connect/6f271e00487e8e09844ced51e3a7223f/ChadCamProjectOverview.pdf?MOD=AJPERES

**** PAK. (2018). The Kribi Port: Presentation. Port Authority of Kribi. Retrieved 15.10.2018, http://www.pak.cm/en/kribi-port/

*** MINEF (MINEP), C.O.C., and BirdLife International. (1999). Cameroon, Important Bird Areas, Field Training in Bird Identification. Yaoundé: MINEF Resource Document.

*** Ministry of Forestry and Fauna. (2007). Aires Protégées: Situation sur la Faune 2006 Yaoundé: DFAP-MINFOF.

*** MINTOUR (2011). Ministry of Tourism and Leisure: Missions. Retrieved October 15, 2018, from MINTOUR website: http://www.mintour.gov.cm/index.php//content/view/full/78.

*** NIS. (2005). Cameroon: Country Profile. National Institute of Statistics. Retrieved August 20, 2009, from: http://www.statistics-cameroon.org/.

*** UNESCO. (2008). The Dja Faunal Reserve. Retrieved January 31, 2008, from UNESCO Web site: http://whc.unesco.org/en/list/407/documents/.

*** Wolfe, D.A., \& Creutzberg, T. (2003). Community participation and multilevel governance in economic development policy. Paper prepared for the panel on the future role of government. Retrieved April o2, 2017, from www.law-lib.utoronto.ca/investing/research_papers.

*** World Conservation Monitoring Centre (WCMC). (1992). Cameroon. Protected Areas of the World: A Review of National Systems. Cambridge: World Conservation Union.

*** World Bank. (2005). Cameroon Forestry/Environment: Integrated Safeguards Data Sheet. Report No: AC533 (Updated). Retrieved March 07, 2018, from Worldbank Web site: http://www-wds.worldbank.org/servlet/ WDSContentServer/WDSP/IB/2004/09/29/000012009_20040929151908/Rendered/INDEX/30077.txt.

*** World Bank. (2018). CM - Lom Pangar Hydropower Proj. (FY12). Retrieved October 16, 2018, from http://projects.worldbank.org/P114077/cm-lom-pangar-hydropower-proj-fy12?lang=en.

*** WTTC. (2018). Travel \& Tourism Economic Impact 2018 - Cameroon, Kenya and Senegal. Retrieved 16.10.2018, from WTTC Web site: https://www.wttc.org/-/media/files/reports/economic-impact-research/countries-2018/.

Submitted:

04.09.2018
Revised:

19.11.2018
Accepted and published online 20.11.2018 